\title{
CORPORATE SOCIAL PERFORMANCE VERSUS FINANCIAL PERFORMANCE OF THE ROMANIAN FIRMS
}

\section{Marian Siminica, Costel Ionașcu, Mirela Sichigea*}

\begin{abstract}
This article analyses the relationship between corporate social performance and financial performance at the level of a panel of 62 Romanian companies listed on the Bucharest Stock Exchange. The first challenge was measuring of the social performance. A new social performance measurement system was developed based on which the CSP Index was obtained. The GRI criteria for reporting, the channel of communication chosen by the companies, as well as the level of detail of the published information were taken into account. The estimation of the regression model was made using the CSP Index as the dependent variable and the financial indicators (return on assets, return on equity, sales growth, average number of employees, total sales, market value added, PER index) as the independent variables. The panel regression analysis done to highlight the fixed or random effects at the company level indicated a relatively weak causal relationship between corporate social performance and financial performance. The social performance may also depend on other variables that are not included in the model, although, the general conclusion was that the social performance of Romanian companies is relatively low, but in an ascending evolution.
\end{abstract}

Keywords: corporate social performance, financial performance, panel data analysis, regression models with fixed or random effects

JEL Classification: M14, C12, A13

\section{Introduction}

The theme of corporate social responsibility has achieved considerate notoriety, the concept being also popularized in various trends and terminologies as corporate social performance, corporate citizenship, responsible business. Even if the official term coined by international institutions such as the European Commission and the World Business Council for Sustainable Development is corporate social responsibility (CSR), according to Karagiorgos (2010, p. 88), in many studies, the measure of CSR is commonly referred to as corporate social performance (CSP). Corporate social performance describes the supposed relationship between corporate social responsibility activities and firm-level corporate financial measures (Dennis et al. 2008, p. 26).

* Marian Siminica, Faculty of Economics and Business Administration, University of Craiova, Romania (msiminica@yahoo.com);

Costel Ionascu, Faculty of Economics and Business Administration, University of Craiova, Romania (icostelm@yahoo.com);

Mirela Sichigea, Faculty of Economics and Business Administration, University of Craiova, Romania (mirelasichigea@gmail.com). 
Corporate social responsibility is a desideratum of the contemporary world and a significant assumption of the business environment (Hristea, 2011, p. 56). Many managers see the CSR as a component of the sustainable development strategy with implications on both the size of costs and the company's earnings. This view indisputably connects a company's social responsibility actions with its financial performance, but the direction of this connection is not exactly known.

Studies on this topic are numerous, but substantially different. They differ not only in terms of the techniques used for analysis but also, in terms of the different methods used to quantify the CSP. All this leads to divergent results even for the same type of economy.

One of the scientific contributions of the hereby work is the development of a system for measuring the corporate social performance of Romanian companies. It is based both on Romanian and international scholars' approaches regarding the CSP measurement. INDEX_CSP was obtained by reporting to the criteria set by the Global Reporting Initiative (GRI) of the data published by the Romanian companies in three kinds of formal information sources. Having a wide range of action and a complex structure, it allows a much more conclusive and complete assessment of the relationship between CSP and CFP.

The results of the econometric analysis have shown a very weak connection between the two concepts for Romanian companies. This result is in accordance with the current reality of the Romanian economy and other countries of Central and Eastern Europe (CEE).

\section{Scientific Literature Review}

\subsection{Measurement of CSP and CFP}

Contrarily to its notoriousness, CSP is a concept that is difficult to be quantified and, thus, to be analysed in an interdependence with other key objectives of a company, such as its financial performance. Assigning figures to the social responsibility actions taken by a company is both a difficult and complex task. According to Wolfe and Aupperle (1991, p. 265) there is no single best way to measure corporate social activities.

The scientific literature showed that the most widely used techniques for quantifying the CSP include: the analysis of information published by companies in specific reports or in general annual reports (Strouhal et al., 2015; Aras et al., 2010; Karagiorgos, 2010), the use of indexes calculated and published by various databases (Madorran, Garcia, 2016; Gherghina, Vintilă, Dobrescu, 2015; Adeneye and Ahmed, 2015; Santoso and Feliana, 2014). According to the conclusion arrived at by Maignan and Ferrell (2000), Aras et al. (2010), these actions are supplemented by an expert review of social responsibility actions, questionnaire-based research and using the measurement of pollution control. As the many authors of studies based on such methods tell us, each of them has both advantages and disadvantages.

Corporate social responsibility is a concept that has become prevalent in company reports in the latest years (Crowther and Aras, 2008, p. 10). The general framework and the guidelines of GRI are the most used for drawing up sustainability reports in companies all over the world (Nuryaman, 2013; KPMG International, 2015). According 
to the provisions of the GRI guidelines (G4. Sustainability Reporting Guidelines, 2014, p. 9) a company should include three main categories of indicators in its report, namely economic, environmental and social. For each category, the Guide stipulates a number of sub-categories and specific indicators. Despite its global growth, CSP reporting varies greatly from one region to another. The rate of CSP reporting by large corporations is consistently higher in Europe than in other parts of the world (KPMG International, 2015). In it, things are still far from being uniform. CSP reporting in Central and Eastern Europe is not as widespread and advanced as in Western Europe (Steurer, Konrad, 2009). The volume and content of the CSP information are also different.

Reporting in accordance with the GRI criteria has been used in many studies to measure the CSP (Madorran and Garcia, 2016; Karagiorgos, 2010; Sutantoputra, 2009).

The main difficulty in measuring social performance is its multi-dimensionality (Chen and Delmas, 2011, p. 790). The recent studies have tried to overcome the issue through a simple linear aggregation of CSP data, in order to create an aggregated CSP score, either for a certain subset of CSP criteria, or for the entire CSP concept. The creation of a CSP index has been used in many studies (Dumitrescu and Simionescu, 2015; Romolini et al., 2014; Karagiorgos, 2010).

If measurement tools for CSP differ from one author to another, things are much more established for CFP measurement. Corporate financial performance was primarily measured through two large categories of indicators (Aras et al., 2010). The first category refers to indicators based on accounting data and such as the return on assets, the return on equity, the return of employed capital and the earnings per share (Madorran and Garcia, 2016; Rajnoha et al., 2017; Adeneye and Ahmed 2015; Simionescu and Gherghina, 2014). The second category refers to market perception-based indicators and includes: market value added and the company's value (Adeneye and Ahmed 2015; Gherghina et al., 2015; Dagilienè, 2014).

These are accompanied by control variables, accepted as factors that determine a company's performance. Indicators of risk, size, and industry, quantified in different ways, have been suggested in literature to be factors that affect a firm's performance (Lech, 2013, p. 56).

\subsection{The relationship between CSP and CFP}

Many authors have studied the relationship between CSP and CFP for many economies undergoing different development phases. However, the review of such articles results in a lack of uniformity regarding the nature of the dependence (positive or negative) between the two concepts. There are conclusions on the lack of a relationship between them.

Most studies prove the existence of a positive correlation between CSP and CFP.

For American economy, the analysis performed by Gherghina, Vintilă and Dobrescu (2015) for a sample of 52 companies listed on the New York Stock Exchange and the NASDAQ Stock Exchange showed a direct positive influence of CSR on a company's value.

Adeneye and Ahmed (2015) used the regression analysis and correlation to study the relationship between CSP and CFP for 500 British companies. The results showed 
a significant positive relationship between CSP, market value added and the return on employed capital.

On the other hand, some studies have shown a negative correlation between CSP and CFP.

Dobre, Stanila and Brad (2015) analysed the impact of indicators regarding the environment protection and social protection on the financial performance of Romanian companies during 2010-2013. The results showed that an enhanced protection of soil, water and air negatively impacts the return on equity, while their influence is non-significant on the return on assets and market value added.

Hirigoyen and Poulain-Rehm (2014) used the regression analysis to study the causality between CSP and CFP for 329 companies listed in three geographical areas (the United States of America, Europe and Asia-Pacific). The results showed that financial performance negatively impacted corporate social performance.

The scientific literature also includes studies, whose results indicated the absence of a statistically significant correlation between CSP and CFP.

Madorran and Garcia (2016) discovered that there was no obvious relationship between corporate social performance and financial results for Spanish companies. The authors studied a sample of 208 Spanish companies from the IBEX 35 stock exchange index for 2003-2010, using panel regression.

Strouhal et al.(2015) reached the same conclusion: the lack of a direct correlation between the implementation of distinct CSR reports and the financial performance of the Czech and Estonian listed companies.

Lech (2013) showed no valid correlation between CSP and CFP of the largest Polish companies listed on the Warsaw Stock Exchange.

The heterogeneity of results is caused both by the different research methodology and especially by how CSP is quantified. This very large variety of results regarding the relationship between CSP and CFP is, in our opinion, a solid argument for going on testing/developing new techniques for the analysis of this causal relationship and for obtaining more uniform results, at least for the same type of economy.

\section{Methodology}

\subsection{Population and Data Sources}

The total population of 84 Romanian companies listed on the Bucharest Stock Exchange (BSE) was used as a starting point of applied research. In a first phase, the companies suspended for trading, financial investment companies and banking companies were discarded, and a population of 62 companies was obtained (Table 1). CSP and CFP were calculated for them. 


\begin{tabular}{|l|c|}
\hline Activity Sector/(company symbol) & Number \\
\hline B. Mining and quarrying (PTR, SNG, SNP) & 3 \\
\hline $\begin{array}{l}\text { C. Manufacturing (ALBZ, ALR, ALT, ARS, ART, ARTE, ATB, BIO, BRM, CBC, CEON, } \\
\text { CMF, CMP, CNTE, ECT, ELGS, ELJ, ELMA, EPT, IARV, MCAB, MECE, MECF, OLT, } \\
\text { PPL, PREB, PREH, ROCE, RRC, RTRA, SCD, SNO, SPCU, STIB, STZ, TBM, TRP, } \\
\text { UAM, UZT, VESY, VNC) }\end{array}$ & 41 \\
\hline D. Electricity, gas, steam and air conditioning production and supply (TEL, SNN) & 2 \\
\hline F. Construction (COTR, IMP) & 2 \\
\hline G. Wholesale and retail; repair of motor vehicles and motorcycles (ALU, PEI, & 4 \\
\hline RMAH, RPH) & 4 \\
\hline I. Hransport and storage (COTE, OIL, SOCP, TGN) & 3 \\
\hline K. Financial and insurance intermediation (BRK, SCPS) & 2 \\
\hline M. Professional, scientific and technical activities (EL) & 1 \\
\hline Total & 62 \\
\hline
\end{tabular}

Source: Own research

The data was collected:

- for CFP: from the annual financial and accounting statements published by companies on the website of the Bucharest Stock Exchange;

- for CSP: from the sustainability reports published on the official websites of the companies, the annual administrators' reports published on the website of the Bucharest Stock Exchange for 2011-2015, as well as articles, brochures or other sources published by each company on its own website.

\subsection{CSP index for BSE-listed Romanian companies}

Considering the scholars' current trend of quantifying the CSP through an aggregated score, the extended area of collection of information regarding social responsibility actions taken by companies, as well as the declared importance of homogenising research techniques, we have pursued the development of a complex system, quantifying the CSP at the level of BSE-listed Romanian companies.

This system was based on the CSP measurement model developed by Karagiorgos (2010, p. 95) for Greek companies, which was improved and updated according to the newest national and international approaches in the field and, at the same time, adapted to the specificities of Romanian economy. 
The model is built on three pillars corresponding to three official sources that may be used by a company for publishing information on its social responsibility actions: sustainability reports, the administrators' reports and their own websites. We mention that these informational sources were also used by other scholars in quantifying the CSP of Romania companies (Dobre et al., 2015; Siminica et al., 2015; Simionescu and Gherghina, 2014) as well as companies from other economies (Karagiorgos, 2010; Strouhal et al., 2015; Dagilienè, 2014).

Environmental and social performance indicators stipulated by GRI in G4, with their own sub-items, have been identified. There have been assigned figures depending on the source of publication of information, as well as according to their degree of detail for each individual company (Appendix 1):

- Companies that published a sustainability report received scores from 0 to 3 . When a company failed to consider an indicator, it received a score of 0 ; a low presentation of an indicator corresponded to 1.5 points; the presentation of concrete information on an indicator was assigned 3 points. The maximum score for this category was 15 points. Remark: Companies drawing up sustainability reports according to GRI standards were assigned one point, independently from the previously detailed assessment.

- Companies whose administrators' report included information on key aspects regarding the environment and employees (as per Chapter 7 "The Administrators' Report", article 491 para (1) of the Accounting Rules approved by Order of the Minister of Public Finance No. 1802/2014) were assigned scores from 0 to 2 . The failure to present information on an indicator was scored with 0 . The low description of the indicator's content resulted in the assignment of one point, while the detailed presentation of the indicator resulted in 2 points. The maximum score for this category was 6 points.

- Companies that published information on their social responsibility actions on their official websites were assigned scores from 0 to 1 . Their exposure on the website, with no presentation of the indicators, resulted in 0 points. The brief presentation of CSP indicators implied the assignment of 0.5 points, while their detailed description implied the assignment of 1 point. The maximum score for this category was 5 points.

The CSR value for a company is obtained by adding the 3 scores, which thus result in a scoring value of maximum 27 points.

Granting the highest score (15 points) in case a sustainability report was published is based on the need and importance of implementing CSR practice in the activity of Romanian companies. The assignment of an extra point for a report that was drawn up according to GRI is integrated in the context of the wide international use of these standards as a benchmark for reporting social responsibility actions (KPMG 2015, p. 42).

A maximum score of 6 points for information published in the administrators' report is substantiated by the fact that, according to the law, companies have to publish information on the two categories of indicators, but the degree of detail of such information is at the discretion of each of them. 
A maximum score of 5 points for information published by each company on its official website is explained by the fact that CSR culture has developed in Romania in the last 10-15 years, and national companies are undergoing a recent process of learning the utility and importance of adopting a business strategy on social responsibility.

\subsection{CFP of Romanian companies}

The financial performance of Romanian companies was measured both by indicators based on accounting data, and by market indicators. They are detailed in the following table.

Table 2 | Financial Performance Indicators

\begin{tabular}{|l|l|}
\hline Symbol of the indicator & Name of the indicator \\
\hline ROA & Return on assets \\
\hline ROE & Return on equity \\
\hline MVA & Market value added \\
\hline GROWTH & Growth of sales \\
\hline PER & PER index \\
\hline SALES & Total sales \\
\hline NO._EMPLOYEES & Average number of employees \\
\hline FIELD OF ACTIVITY & Field of activity \\
\hline CATEG_TURNOVER & $\begin{array}{l}\text { - } \quad \text { large companies, turnover } \geq 900,000,000^{*} \text { lei } \\
\text { small companies, turnover }<900,000,000^{*} \text { lei }\end{array}$ \\
\hline
\end{tabular}

Note: "The 900,000,000-lei threshold was established after the preliminary analysis of data. The analysis revealed the fact that the intensity of CSR actions for the companies with a turnover greater than $900,000,000$ lei increases significantly comparing with the companies with a turnover lower than this value.

Source: Own research

\subsection{Hypotheses development and model specification}

Considering previously mentioned aspects, the hereby work aims at developing a system for assessing social responsibility actions of Romanian companies, that would result in a CSP index allowing for a conclusive analysis of its relationship with the financial performance (CFP) of Romanian companies.

The following set of study hypotheses is proposed to this purpose:

$\mathrm{H}_{0}$ : There is a statistically significant correlation between the CSP and CFP of Romanian companies;

$\mathrm{H}_{1}$ : There is no statistically significant correlation between the CSP and CFP of Romanian companies. 
If a statistically significant dependence is confirmed, the research will be pursued with the study of the regression between the selected variables.

The analysis of the causal relationship between CSP and CFP for Romanian companies listed on the BSE, will be performed using a linear regression model or a panel regression model. The decision is argued depending on the existence/absence of the individual effect $\boldsymbol{u}_{\boldsymbol{i}}$ (from a company to another or in time), in longitudinal data.

Thus:

- $\quad$ if the individual effect does not exist $\left(\boldsymbol{u}_{\boldsymbol{i}}=0\right)$, the method of the ordinary least squares (OLS) helps obtain consistent and efficient estimates of the regression model parameters;

- $\quad$ if the individual effect exists in longitudinal data $\left(\boldsymbol{u}_{\boldsymbol{i}} \neq 0\right)$, it is highly possible that some of the hypotheses lying at the basis of the multiple linear regression model are no longer met. In this case, panel data regression analysis is a way to estimate this individual effect at a company/company group level, in time or both. Such effects may be fixed or random.

\section{Results and Discussions}

The CSP Index values were obtained for each company after we have analysed the CSR information published by the 62 Romanian companies and we have followed the methodology presented above. The distribution of the analysed companies according to the value of this index, for each year of the analysed period, is presented in Appendix 2.

In 2011, 17 companies did not provide any information regarding social responsibility actions and one company (SNP) published detailed CSR information that exceeded the minimum required by the national legislation in force. The average CSP Index was 2.92 points, representing only $10.8 \%$ of the maximum score that can be awarded ( 27 points).

In the next years, the situation has improved, the involvement of companies in social responsibility actions becoming stronger and stronger. Thus, in 2012, only 4 companies in the analysed sample did not report social responsibility actions, in 2013 their number was reduced to 2 companies and in the years 2014 and 2015 all the companies analysed reported such actions.

The average CSP Index rose to 3.85 points in 2013 (representing a 32\% increase over the previous year), then to 4.24 points in 2014 (a 10\% increase) and to 4.42 points in 2014 (a $4 \%$ increase). In 2015, its level slightly fell by about $2 \%$.

The evolution of the average level of the CSP Index confirms the tendency to increase the involvement of listed companies in social responsibility actions, but this is still low. Compared to the maximum level that can be attributed to the CSP Index (27 points), its actual value is around $16 \%$, which shows that the Romanian listed companies are still at an early stage of involvement in social responsibility actions. Only one of the 62 companies in the sample (SNP) had a significant involvement in such actions.

Based on these data, we built a statistical distribution of the companies in the sample, by grouping intervals, according to the level of the CSP Index. We specify the fact that 11 points 
represent the maximum score for companies that published CSR information on official websites and administrators' reports (see the rating grid in Appendix 1). Based on this criterion, the first interval of the CSP Index values was built. The same 11-point step is also applied in the construction of the second interval, while the last interval delimits the values up to the final threshold, the maximum score to be obtained.

Figure 1 | Index CSP per Year and Activity Sector

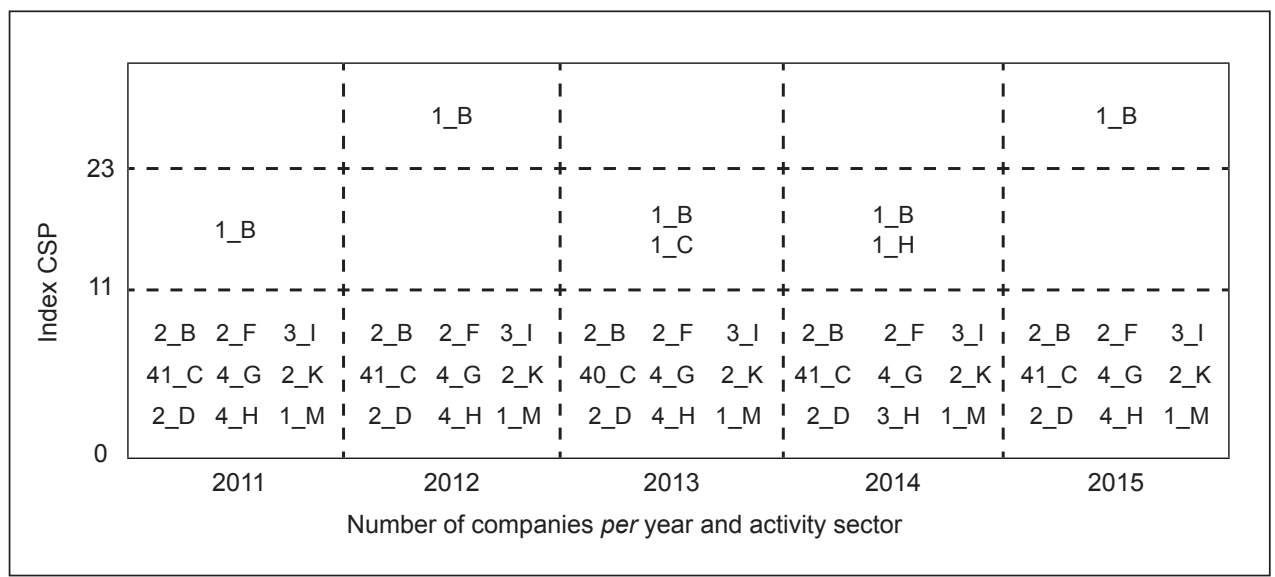

Note: $\mathrm{B}=$ Mining and quarrying; $\mathrm{C}=$ Manufacturing; $\mathrm{D}=$ Electricity, gas, steam and air conditioning production; and supply; $\mathrm{F}=$ Consruction; $\mathrm{G}=$ Wholesale and retail; repair of motor vehocles and motorcycles; $\mathrm{H}=$ Transport and storage, $\mathrm{I}=$ Hotels and restaurants, $\mathrm{K}=$ Financial and insurance intermediation; $M=$ Professional, scientific and technical activities

Source: Own Research

A comparative analysis by sectors of activity (Figure 1) reveals that the 3 companies, which have obtained superior values for the CSP Index are from Mining and quarrying industries, (SNP with 18 points in 2011, 26 points in 2012, 23 points in 2013 and 2014 and 26 points in 2015), Manufacturing (OLT with 16 points in 2013) and Transport and storage (TGN with 22 points in 2014). They have developed separate sustainability reports detailing the relevant aspects of CSR. By contrast, regardless of the field of activity, the CSR information published by the Romanian companies concerned only the aspects regarding the employees, the environment (mandatory indicators to be presented in the administrator's report) and the local community (predominantly on company websites).

Financial performance indicators are characterized by relatively uniform sizes within the analysed time frame, with a slightly upward trend. SNP has a higher financial performance throughout the analysed period. We find that the highest social performance is achieved by the company with the highest level of financial results.

The observation of the quantitative analysis, as well as the results of the studies already undertaken (Dobre et al., 2015; Gherghina et al., 2015) represent the basis for the stage of estimation of the regression model that best characterizes the causal relationship between CSP and CFP for Romanian companies. According to the scientific hypothesis, we can 
expect the financial performance indicators to positively influence the CSR Index (CSR actions) or negatively (stakeholders are only interested in the financial performance, CSR actions being considered as unnecessary costs). The lack of a relationship between the variables is the alternative hypothesis.

The estimation of the regression model was made using the Index CSP as the dependent variable and the financial performance indicators (ROA, ROE, MVA, GROWTH, PER, SALES, NO._EMPLOYEES, and CATEG_TURNOVER) as independent variables. The field of activity was the control variable. Multiple linear regression and panel regression methods were used, both with fixed effects, and with variable effects (see Appendix 3).

After preliminary tests, it was observed that the CSP Index was not significantly correlated with ROA, ROE, Sales growth and the PER Index. For the Romanian companies analysed it could not be proved that these financial results can be a determinant factor of their involvement in social responsibility actions. These variables were excluded from the analysis. A number of 5 companies (EPT, OLT, PEI, SCPS, EL) from the 62 were discarded, due to a lack of financial information for the analysed period (2011-2015) or to the irrelevance generated by the values of financial indicators regarding total CSP.

The first estimated model is that of multiple linear regression (Appendix 3). According to it, the CSP Index is positively influenced by MVA and NO._EMPLOYEES. The increase in social performance is obtained together with the growth of the company's size, appreciated by the average number of employees and the improvement of its market value. However, the variable set as the turnover threshold (CATEG_TURNOVER) is negatively correlated with Index_CSP. This result is surprising, but the econometric model containing is statistically weak (explains only about 39\% of the Index_CSP variation).

The classical regression model does not emphasize the variability of individual effects in time or from one company to another, which is why we have aimed at refining it by using another type of model that could show this, i.e. the panel data regression model. This improvement attempt is based on the fact that certain features of companies influence the likelihood that they may develop CSP actions (for instance, a large company is more likely to perform CSP actions, since it has more resources than a small one).

We have tested whether statistically significant fixed effects (FE) exist within the panel (Appendix 3) using F test. The FE model eliminates the CATEG_TURNOVER variable (due to the fact that it does not vary in time at the level of each company), validating the positive relationship of Index_CSP with MVA and NO._EMPLOYEES . Using the LSDV method, the existing individual FE in companies, were quantified (Appendix 3). Estimating the model with the dummy variable set for each included company, excepting the company 57 (BRK), which was kept outside the model as a reference level, the set of statistically significant coefficients was obtained for companies where the FE is present. The fixed effects are only present in seven companies in the Mining and Quarrying (PTR, SNP), Manufacturing (MECE, UZT, VNC), Construction (COTR), Wholesale and Retail (ALU) industries. The BRK company, used as the reference level, is added to them. It belongs to the financial and insurance intermediation industry. For the rest of the companies there are not statistically significant differences between their individual level and the reference level. 
Individual regression models for each of the eight companies with significant (Appendix 3) were estimated. These models indicate a positive relationship between the CSP Index and the MVA. Only companies with increasing MVA record higher social performance. Analysing the models resulted for each of all eight companies, it seems that these companies can be organised in three categories (Figure 2). The first category includes only SNP, the second includes all of the rest of the companies, except BRK, which is included in the third category.

Figure 2 | Correlation between CSP_Index and MVA

a) All eight companies

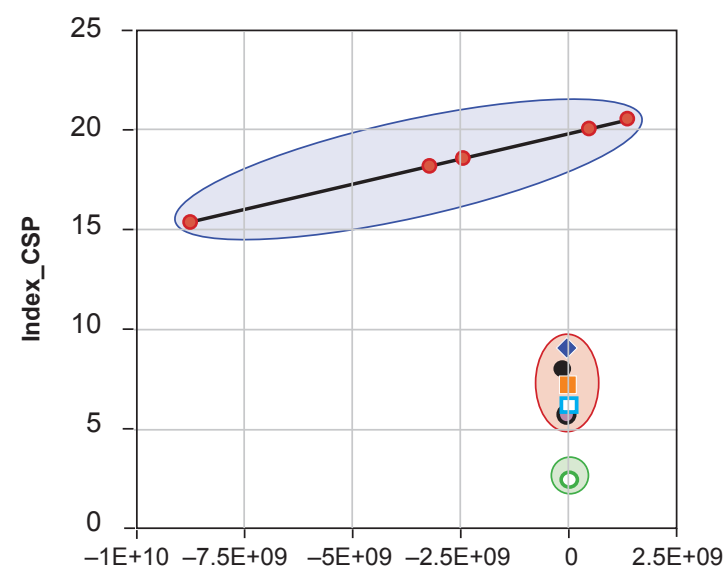

MVA

b) Detailed view for companies except SNP

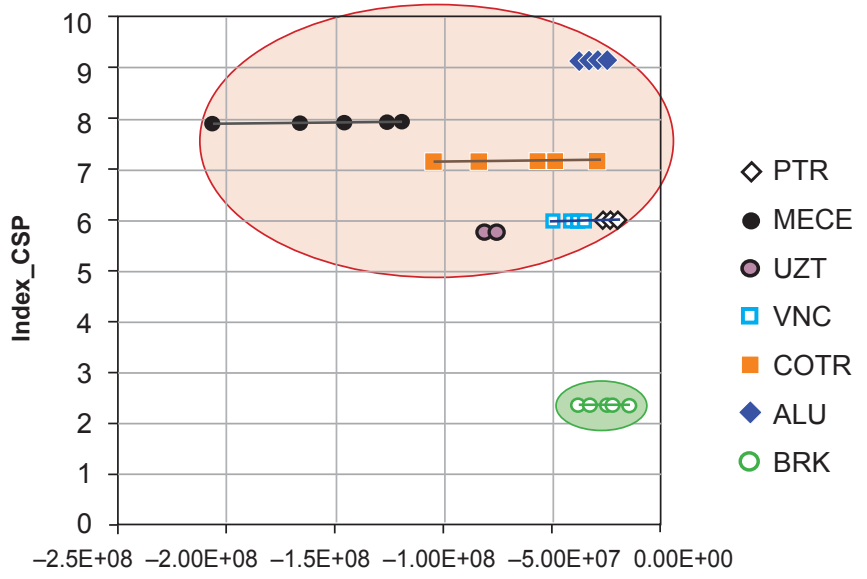

MVA 
It has been found that, due to the existence of statistically significant individual FE, the levels for CSP_Index are higher by 3.604 in PTR, by 17.391 in SNP, by 5.595 in MECE, by 3.408 in UZT, by 3.590 in VNC, by 4.802 in COTR, respectively by 6.748 in ALU, compared to the chosen benchmark, i.e. the CSP_Index value of BRK.

It was tested whether random effects (RE) exist within the panel, using Breusch and Pagan LM test. The obtained results indicate the existence of low RE, only $23.2 \%$ of the total variation of composite error could be explained by means of this model (Appendix 3).

Similar to the classic regression model, the RE model also shows a positive relationship of CSP_Index with MVA and NO._EMPLOYEES and a negative relationship with the CATEG_TURNOVER variable. Companies that create market value and benefit from superior human resource compared to the average of the sector (both numerically and qualitatively) are involved in social responsibility actions. The negative correlation with CATEG_TURNOVER is a surprising result, indicating that social performance is decreasing as companies' turnover is increasing. However, a more detailed analysis indicates that this result is generated by the fact that very few performing companies (with higher turnover) are involved in CSR actions, while the vast majority of the analysed companies are not. At first glance, the negative relationship between the CSP_Index and the variable set as the turnover threshold (CATEG_TURNOVER) seems to contradict the scientific literature. In the European context, Que're' et al. (2015) obtained a negative and significant link between the CSR rating agency and the growth rate of turnover at the level of the companies evaluated by a CSR rating agency (Vigeo).

The decision for choosing the best of the three types of the analysed models for Romanian companies was based on the results from the testes F, Breusch and Pagan LM and the Hausman. The RE model is the regression model that best captured the causal link between CSP and CFP for the Romanian analysed companies. The equation of the model is:

$$
C_{-} \text {Index }_{i t}=5.288+3.52 \cdot 10^{-10} \cdot M V A_{i t}+0.0009 \cdot N_{\text {EMPLOYEES }_{i t}}-2.04 \cdot \text { CATEG }_{\text {TURNOVER }_{i t}}
$$

This model explains only in a low proportion the dependence between the contained variables. Trying to use Chow test to study the slope stability inside the panel, we obtained that selected random effects model can cause confusion regarding the causal relation between its variables because the individual error variance components do not follow a normal distribution. It can be said that, at the level of the studied panel, CSP does not depend on the analysed variables, but, eventually, it may depend on other variables that are not contained by this model.

In other words, our model suggests that the statement "doing good by doing well" is not valid for the Romanian companies analysed. However, it is necessary to place our research in the context of the region Romania is part of.

The results of our research are consistent with the conclusions drawn by other studies from the Central and Eastern Europe (CEE). Thus, in a study carried out, from 28 companies (listed on Nasdaq OMX Baltic 15 and 23 to Prague Stock Exchange) for 2012-2013 
(Strouhal et al., 2015, p. 52), the authors investigated the existence of a correlation between publishing separate CSR reports and the financial performance of companies. The results showed that there was not a correlation between the publication of separate CSR reports and the financial performance of companies. In another study carried out at 30 companies listed on Vilnius Stock Exchange Market in Lithuania, it was observed that the CSR reporting activity did not influence the value of ROA and MVA indicators (Dagiliene, 2014). CSR engagement is not significantly related to the firm risk in the Polish public companies listed on the Warsaw Stock Exchange (Chojnacka, 2016).

Figure 3 | Index CSP Values Distribution by Turnover and Year

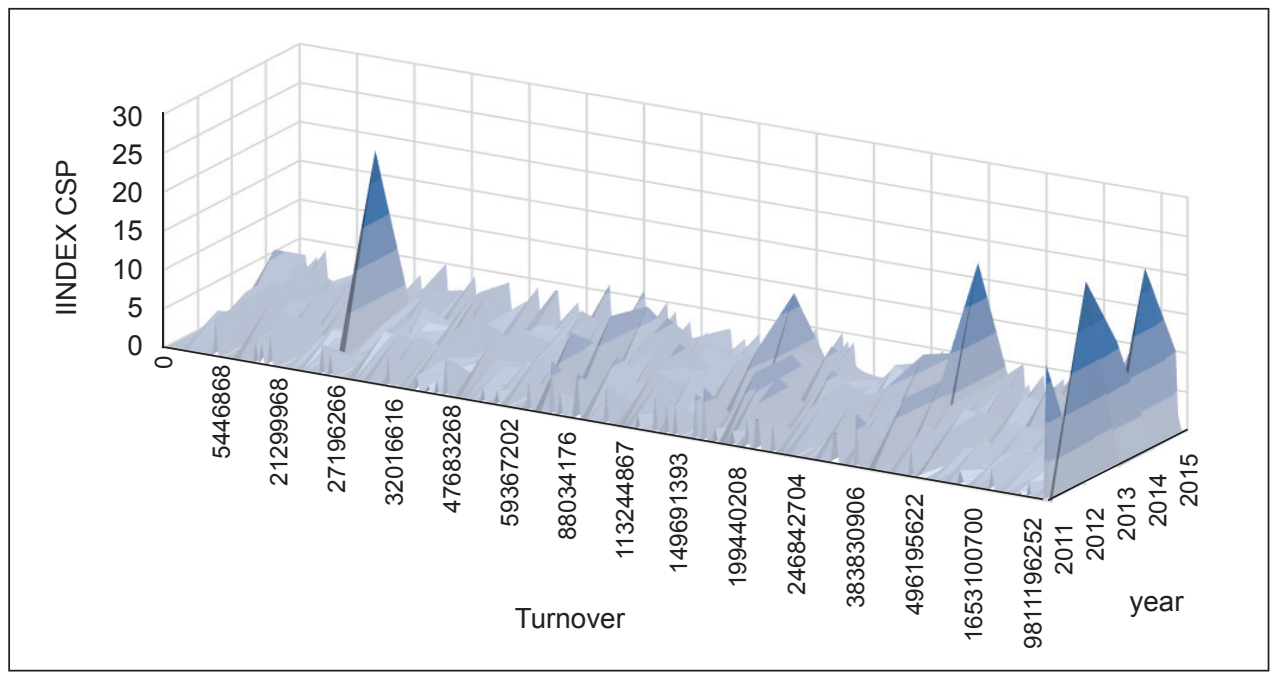

Source: Own research.

Corporate Social Responsibility is still in the development phase for the companies in the CEE countries and implicitly for those in Romania. Poor corporate culture in this area is reflected in the results of empirical research. However, the existence of a strong relationship between CSR and CFP is demonstrated by studies conducted for developed markets, especially Western European firms (Adeneye and Ahmed, 2015, Romolini et al., 2014) or the USA (Gherghina et al., 2015, Akisik and Gal, 2014). In their case, the decadelong advance in CSR implementation is reflected in a much greater availability of data and numerous social performance measurement methodologies.

\section{Conclusions}

The objective of analysing the relationship between social and financial performance is ambitious, especially because the concept of corporate social responsibility is relatively a new one in the Romanian economy. Unlike the developed markets where this concept emerged and developed (those in Western Europe and the USA), companies in CEE countries, including the Romanian ones, are barely making the first steps in integrating 
CSR into their business practice. Implementing CSR principles in company development strategy, as well as communicating concrete actions to stakeholders, takes time. Things are not much different in terms of CSR literature as well. The number of Western European (WE) studies is well above those of CEE companies. The gap between the two generic economies, Western and Eastern Europe, will only be reduced by sustained effort over time. Skýpalová et al. (2016) came to a similar conclusion.

In this context, the present paper identifies the real stage of CSR practice and communication at the level of the Romanian companies listed on the BSE and studies the causal relationship between their social and financial performance. The first challenge we assumed was the CSP measuring. In the absence of methodologies or independent bases for assessing the social performance of Romanian companies, we updated, improved and adapted to the specifics of the Romanian economy a model of CSP measurement developed by Karagiorgos (2010) for Greek companies. The measurement system we have proposed integrates the newest, national and international approaches to social performance and leads to a complex index. The CSP index is obtained by aggregating scores from three official channels of information communication regarding corporate social responsibility. The GRI Reporting Criteria and the degree of detail information are the basis for the scores for each company. The maximum CSP Score is 27 points and consists of 15 points for publishing a sustainability report plus one point for publication, according to GRI criteria; 6 points for the publication of non-financial information only in the administrator's report, according to the national legislation in force; 5 points for publishing non-financial information on official company websites. For Romanian companies, this way of quantifying CSP is the first attempt to aggregate, in one index, the information published through three official sources.

We consider that our research makes a significant contribution to the technical literature by developing a new social performance measurement system (the CSP Index). It can be a starting point for future research, both at the level of Romanian companies, and those in other Central and Eastern European states.

The index of social performance was calculated for a sample of 62 Romanian companies listed on the BSE. The analysis targeted the period 2011-2015 and led to the general conclusion that the social performance of Romanian companies is relatively low, but in an ascending evolution. The CSP Index's individual values show a strong concentration in the range of $0-11$ points, specific to companies that provide information only through the site and the Administrator's report. However, the average CSP index increased during the analysed period from 2.92 points in 2011 to 4.34 points in 2015 , signifying an increase in Romanian companies' interest in such activities.

Detailed information on social responsibility was published by only a small part of the analysed Romanian companies (SNP, throughout the analysed period, publishing annual sustainability reports, including GRI; OLT in 2013 and TGN in 2014). In terms of the activity carried out (SNP - crude oil extraction, OLT - chemicals production, TGN pipeline transport of natural gas) these are companies with visible effects on the environment and / or population's quality of life. Involvement and communication of CSR actions contribute to improving the image of their brand and, implicitly, their financial performance. 
The vast majority of Romanian companies, however, limited themselves to the minimum imposed by the national legislative framework and published only information on employees and the protection of the environment (mandatory indicators to be presented in the administrator's report). Companies that also used the official site to submit CSR information mainly disclosed information regarding the involvement in community projects.

The financial performance was measured using a set of eight indicators: ROA, ROE, MVA, GROWTH, PER, SALES, NO._EMPLOYEES, and CATEG_TURNOVER. The general trend was a slight increase in these indicators, signifying an increase in the financial performance of the companies analysed.

Based on the results obtained regarding the social performance (CSP) and the financial performance (CFP) of the companies included in the sample, we estimated the regression model that best captured the causal link between them. To this purpose, we used the technique of multiple linear regression and panel regression technique with fixed effects and variable effects. The CSP Index was used as the dependent variable, and the financial indicators as independent variables. The field of activity was the control variable. Preliminary estimates of regression models showed that there is no significant link between the ROA, ROE, GROWTH and PER variables that measure the financial performance of the companies analysed and the CSP Index, which also corresponds to the findings (Madorran and Garcia 2016, Strouhal et al., 2015, Lech 2013). The only dependent variables retained in the estimation of regression models were MVA, NO._EMPLOYEES and CATEG_ TURNOVER. The classic and panel models were estimated at a sample of 57 Romanian companies listed on the BSE ( 5 companies were eliminated in the preliminary test stage).

Of the estimated models, the linear regression model and the random effects model indicated a positive relationship between the CSP Index, MVA and NO._EMPLOYEES, and a negative link with CATEG_TURNOVER. The FE model eliminates the CATEG TURNOVER variable (due to the fact that it does not vary in time at the level of each company), validating the positive relationship of Index CSP with MVA and NO._EMPLOYEES.

Regarding the percentage and clarity in which the variability of the independent variables explains the variance of the dependent variable, the RE model is superior to the other two models. However, the RE model only partially explains the variation of the CSP Index on the basis of financial performance indicators, with other non-financial variables influencing the social performance. The estimated RE model indicates that only companies that create market value and a headcount higher than average are the ones that are experiencing an increase in their social performance. The negative link between the CSP Index and CATEG_TURNOVER contradicts the economic theory by suggesting that a company's social performance may increase when it decreases sales revenue. A more detailed analysis indicates that this result is generated by the fact that very few companies with a higher turnover are involved in CSR actions, while the vast majority of the analysed companies are not, a fact also seen in other European studies (Que're' at al., 2015).

The findings of our study are not in line with the results of other researches for Romanian companies, converging towards a negative influence of the CSP on the CFP (Dobre, Stanila and Brad 2015; Simionescu and Gherghina, 2014). However, they are in accordance with 
the conclusions drawn by other studies from the Central and Eastern Europe (Chojnacka, 2016, Strouhal et al., 2015, (Dagilienè, 2014) and from other economies (Madorran and Garcia, 2016, Lech, 2013), i.e. that there is a low causal dependency between CSP and CFP.

\section{Appendix}

\section{Appendix 1 | CSP Evaluation Form}

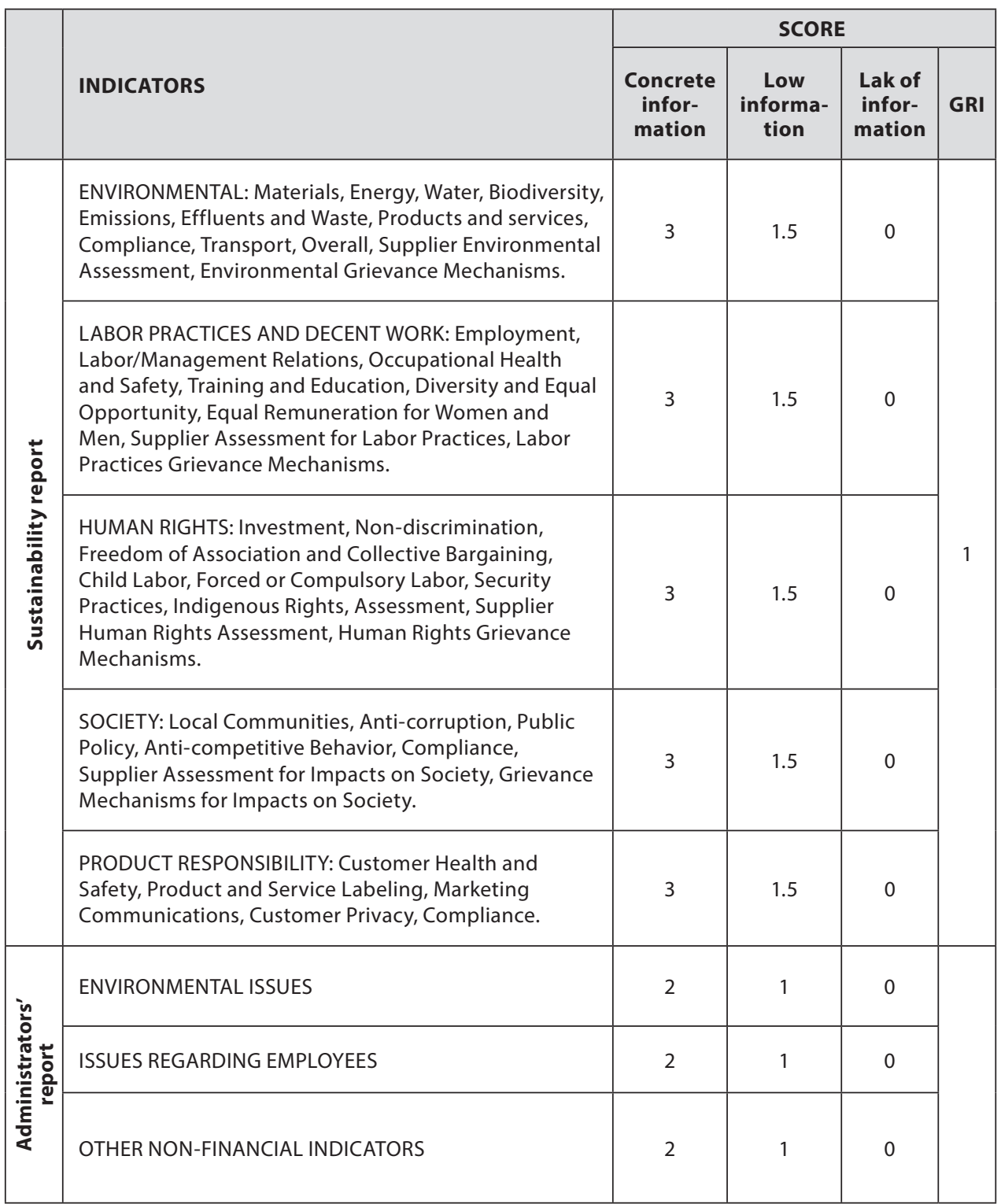




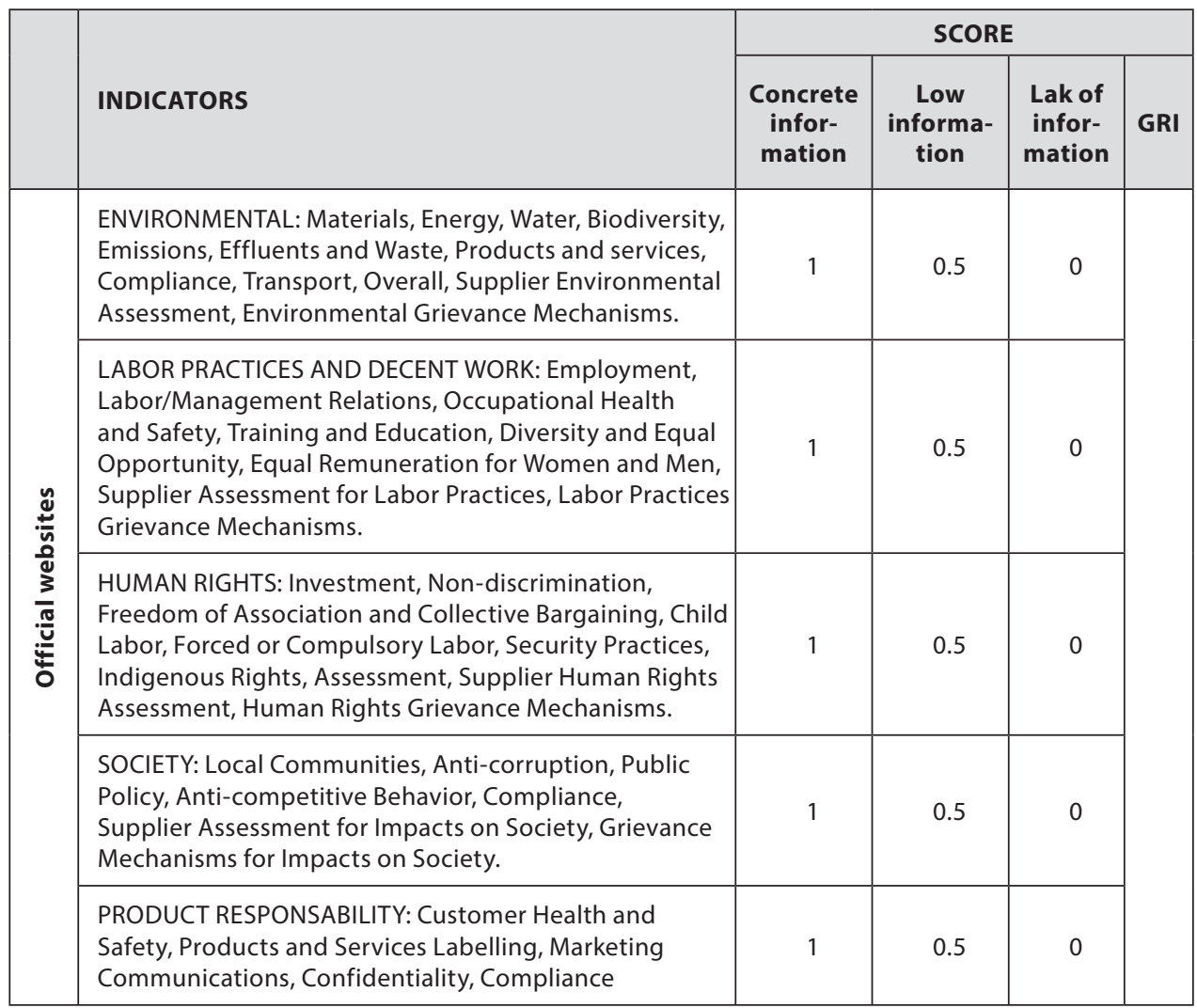

Annex 2 | Distribution of the number of companies by CSP Index

\begin{tabular}{|l|c|c|c|c|c|c|c|c|c|c|c|}
\hline Points & $\mathbf{2 0 1 1}$ & $\mathbf{2 0 1 2}$ & $\mathbf{2 0 1 3}$ & $\mathbf{2 0 1 4}$ & $\mathbf{2 0 1 5}$ & Points & $\mathbf{2 0 1 1}$ & $\mathbf{2 0 1 2}$ & $\mathbf{2 0 1 3}$ & $\mathbf{2 0 1 4}$ & $\mathbf{2 0 1 5}$ \\
\hline $\mathbf{0}$ & 17 & 4 & 2 & - & - & 14 & - & - & - & - & - \\
\hline $\mathbf{1}$ & 4 & 2 & 1 & 1 & - & 15 & - & - & - & - & - \\
\hline $\mathbf{2}$ & 9 & 14 & 12 & 12 & 10 & 16 & - & - & 1 & - & - \\
\hline $\mathbf{3}$ & 6 & 10 & 12 & 13 & 15 & 17 & - & - & - & - & - \\
\hline $\mathbf{4}$ & 12 & 15 & 15 & 17 & 17 & 18 & 1 & - & - & - & - \\
\hline $\mathbf{5}$ & 7 & 9 & 11 & 10 & 10 & 19 & - & - & - & - & - \\
\hline $\mathbf{6}$ & 2 & 2 & 2 & 3 & 5 & 20 & - & - & - & - & - \\
\hline $\mathbf{7}$ & 4 & 4 & 4 & 3 & 3 & 21 & - & - & - & - & - \\
\hline $\mathbf{8}$ & - & 1 & 1 & 1 & - & 22 & - & - & - & 1 & - \\
\hline $\mathbf{9}$ & - & - & - & - & 1 & 23 & - & - & 1 & 1 & - \\
\hline $\mathbf{1 0}$ & - & - & - & - & - & 24 & - & - & - & - & - \\
\hline $\mathbf{1 1}$ & - & - & - & - & - & 25 & - & - & - & - & - \\
\hline $\mathbf{1 2}$ & - & - & - & - & - & 26 & - & 1 & - & - & 1 \\
\hline $\mathbf{1 3}$ & - & - & - & - & - & 27 & - & - & - & - & - \\
\hline $\mathbf{6 S P}$ Index - average value & \multicolumn{1}{|r|}{} \\
\hline
\end{tabular}

Source: Own research 
Annex 3 | Statistical Outputs

Results of linear regression model

\begin{tabular}{|l|c|c|c|}
\hline Independent Variable & Coefficients & $\mathbf{t}$ & $\mathbf{P}>|\mathbf{t}|$ \\
\hline MVA & $3.08 \mathrm{e}^{-10}$ & 2.61 & 0.010 \\
\hline NO._EMPLOYEES & 0.0008964 & 13.06 & 0.000 \\
\hline CATEG_TURNOVER & -2.111348 & -3.90 & 0.000 \\
\hline _CONS & 5.356992 & 9.08 & 0.000 \\
\hline Prob > F = 0.0000; Adj R-squared $=0.3884$ \\
\hline
\end{tabular}

Source: Own research

Results of panel regression with fixed effects

\begin{tabular}{|l|c|c|c|}
\hline Independent Variable & Coefficients & $\mathbf{t}$ & $\mathbf{P}>|\mathbf{t}|$ \\
\hline MVA & $4.29 \mathrm{e}^{-10}$ & 2.88 & 0.004 \\
\hline NO._EMPLOYEES & 0.0006844 & 1.43 & 0.153 \\
\hline CATEG_TURNOVER & 0 & & (omitted) \\
\hline CONS & 3.219019 & 5.66 & 0.000 \\
\hline F test that all u_i $=0: \quad F(56,226)=2.75$ & Prob $>F=0.0000$ \\
\hline$F(2,226)=8.46$ & Prob $>\mathrm{F}=0.0003$ \\
\hline
\end{tabular}

Source: Own research

Results of the LSDV regression

\begin{tabular}{|l|c|c|c|}
\hline Independent Variable & Coefficients & $\mathbf{t}$ & $\mathbf{P}>|\mathbf{t}|$ \\
\hline MVA & $5.20 \mathrm{e}^{-10}$ & 3.85 & 0.000 \\
\hline PTR & 3.604201 & 2.59 & 0.010 \\
\hline SNP & 17.39108 & 12.15 & 0.000 \\
\hline MECE & 5.594785 & 4.02 & 0.000 \\
\hline UZT & 3.408329 & 2.45 & 0.015 \\
\hline VNC & 3.590087 & 2.18 & 0.030 \\
\hline COTR & 4.802300 & 3.45 & 0.001 \\
\hline ALU & 6.747891 & 4.85 & 0.000 \\
\hline CONS & 2.414231 & 2.45 & 0.015 \\
\hline Prob > F = 0.000; Adj R-squared $=0.5211$ \\
\hline
\end{tabular}

Source: Own research 
Particularised regression models

\begin{tabular}{|c|c|}
\hline Company & The resulting regression model \\
\hline SNP & INDEX_CSP ${ }_{t}=19.805+5.20 \cdot 10^{-10} \cdot \mathrm{MVA}_{t}$ \\
\hline ALU & INDEX_CSP ${ }_{t}=9.162+5.20 \cdot 10^{-10} \cdot M^{\prime} A_{t}$ \\
\hline MECE & INDEX_CSP ${ }_{t}=8.009+5.20 \cdot 10^{-10} \cdot M A_{t}$ \\
\hline COTR & INDEX_CSP $P_{t}=7.217+5.20 \cdot 10^{-10} \cdot M^{\prime} A_{t}$ \\
\hline PTR & INDEX_CSP $P_{t}=6.018+5.20 \cdot 10^{-10} \cdot M^{\prime} A_{t}$ \\
\hline VNC & INDEX_CSP ${ }_{t}=6.004+5.20 \cdot 10^{-10} \cdot M^{\prime} A_{t}$ \\
\hline UZT & INDEX_CSP ${ }_{t}=5.823+5.20 \cdot 10^{-10} \cdot M_{t}$ \\
\hline BRK & $I N D E X \_C S P_{t}=2.414+5.20 \cdot 10^{-10} \cdot M V A_{t}$ \\
\hline
\end{tabular}

Source: Own research

Results of panel regression with random effects

\begin{tabular}{|l|c|c|c|}
\hline Independent Variable & Coef. & $\mathbf{z}$ & $\mathbf{P}>|\mathbf{z}|$ \\
\hline MVA & $3.52 \mathrm{e}^{-10}$ & 2.95 & 0.003 \\
\hline NO._EMPLOYEES & 0.0008951 & 9.50 & 0.000 \\
\hline CATEG_TURNOVER & -2.039833 & -2.75 & 0.006 \\
\hline CONS & 5.288341 & 6.51 & 0.000 \\
\hline $\begin{array}{l}\text { rho }=.23227705 \\
\text { Wald chi2(2) }=.\end{array}$ \\
\hline
\end{tabular}

Source: Own research

\section{References}

Adeneye, Y. B., Ahmed, M. (2015). Corporate Social Responsibility and Company Performance. Journal of Business Studies Quarterly, 7(1), 151-166.

Akisik, O., Gal, G. (2014). Financial Performance and Reviews of Corporate Social

Responsibility Reports. Journal Management Control, 25, 259-288, https://doi.org/ 10.1007/ s00187-014-0198-2

Aras, G., Aybars, A., Kutlu, O. (2010). Managing Corporate Performance: Investigating the Relationship between Corporate Social Responsibility and Financial Performance in Emerging Markets. International Journal of Productivity and Performance Management, 59(3), 229-254, https://doi.org/10.1108/17410401011023573

Chen, C. M., Delmas, M. (2011). Measuring Corporate Social Performance: An Efficiency Perspective. Production and Operations Management, 20(6), 789-804, https://doi.org/10.1111/J.1937-5956.2010.01202.X 
Chojnacka, E. (2016). The Relationship Between CSR Engagement and Firm Risk in Polish Public Companies, Springer International Publishing Switzerland, in Bilgin, M. H. et al., eds., Business Challenges in the Changing Economic Landscape-1. Eurasian Studies in Business and Economics 2/1, https://doi.org/10.1007/978-3-319-22596-8_15

Crowther, D., Aras, G. (2008). Corporate Social Responsibility. Ventus Publishing ApS, ISBN 978-87-7681-415-1.

Dagilienè, L. (2013). The Influence of Corporate Social Reporting to Company's Value in a Developing Economy. Procedia Economics and Finance, 5, 212-221, https://doi.org/10.1016/ S2212-5671(13)00027-0

Dennis, B., et al. (2008). Corporate Social Performance: Creating Resources to Help Organizations Excel. Global Business and Organizational Excellence, 27(2), 26-41, https://doi.org/10.1016/S2212-5671(13)00027-010.1002/joe.20192

Dobre, E., Stanila, G. O., Brad, L. (2015). The Influence of Environmental and Social Performance on Financial Performance: Evidence from Romania's Listed Entities. Sustainability, 7(3), 2513-2553, https://doi.org/10.3390/su7032513

Dumitrescu, D., Simionescu, L. (2015). Empirical Research Regarding the Influence of Corporate Social Responsibility (CSR) Activities on Companies' Employees and Financial Performance. Economic Computation \& Economic Cybernetics Studies \& Research, 49(3), 52-66.

Gherghina, Ş. C., Vintilă, G., Dobrescu, D. (2015). An Empirical Research on the Relationship between Corporate Social Responsibility Ratings and US Listed Companies'Value. Journal of Economics Studies and Research, 1-12, https://doi.org/10.5171/2015.260450

Global Reporting Initiative, G4 Sustainability Reporting Guidelines, Available at: https://www. globalreporting.org/standards/g4/Pages/default.aspx, accessed on 12.04.2016;

Hirigoyen, G., Poulain-Rehm, T. (2014). Causal Relationships between Corporate Social Responsibility and Financial Performance: an International Approach, Gestion 2000, 31(2), 153-177.

Hristea, A. M. (2011). Responsabilitatea social corporativă - între deziderat şi realitate, Economie teoretică şi aplicată, 18, 10(563), 56-73.

Karagiorgos, T. (2010). Corporate Social Responsibility and Financial Performance: An Empirical Analysis on Greek Companies. European Research Studies, 13(4), 85-108.

KPMG (2015). The KPMG Survey of Corporate Responsibility Reporting 2015. Available at: https://www.kpmg.com/CN/en/IssuesAndInsights/ArticlesPublications/Documents/ kpmg-survey-of-corporate-responsibility-reporting-2015-O-201511.pdf

Lech, A. (2013). Corporate Social Responsibility and Financial Performance. Theoretical and Empirical Aspects. Comparative Economic Research, 16(3), 49-62, https://doi.org/10.2478/ cer-2013-0018

Madorran, C., Garcia, T. (2016). Corporate Social Responsibility and Financial Performance: the Spanish Case. Revista de Administracao de Empresas, 56(1), 20-28, https://doi.org/10.1590/S0034-759020160103

Maignan, I., Ferrell, O. C. (2000). Measuring Corporate Citizenship in Two Countries: The Case of the United States and France. Journal of Business Ethics, 23(3), 283-297, https://doi.org/10.1023/A:1006262325211

Nuryaman, C. (2013). The Effect of Corporate Social Responsibility Activities on Profitability and Stock Prices (Studies on the companies listed on Indonesia Stock Exchange), Journal of Global Management, 6(1), 113-124. 
Que're', B. P., Nouyrigat, G., Baker, C. R. (2015). A Bi-Directional Examination of the Relationship between Corporate Social Responsibility Ratings and Company Financial Performance in the European Context. Journal of Business Ethics, 1-18, https://doi.org/10.1007/ s10551-015-2998-1

Rajnoha, R., Lesníková, P., Krajčík, V. (2017). Influence of Business Performance Measurement Systems and Corporate Sustainability Concept to Overal Business Performance: "Save the Planet And Keep Your Performance". Business Administration and Management, 20(1), 111-127, https://doi.org/10.15240/tul/001/2017-1-008

Romolini, A., Fissi, S. Gori, E. (2014). Scoring CSR Reporting in Listed Companies - Evidence from Italian Best Practices, Corporate Social Responsibility and Environmental Management, 21(2), 65-81, https://doi.org/10.1002/csr.1299

Santoso, A. H., Feliana, Y. K. (2014). The Association between Corporate Social Responsibility and Corporate Financial Performance. Issues in Social and Environmental Accounting, 8(2), 82-103, https://doi.org/10.22164/isea.v8i2.86

Simionescu, L. N., Gherghina, Ș. C. (2014). Corporate Social Responsibility and Corporate Performance: Empirical Evidence from a Panel of the Bucharest Stock Exchange Listed Companies. Management \& Marketing. Challenges for the Knowledge Society, 9(4), 439-458.

Siminică, M., Crăciun, L., Dinu, A. (2015). The Impact of Corporate Sustainability Strategies on the Financial Performance of Romanian Companies in the Context of Green Marketing, Amfiteatru Economic, 17(40), 994-1010.

Skýpalová, R., Kučerová, R., Blašková, V. (2016). Development of the Corporate Social Responsibility Concept in Small and Medium-Sized Enterprises. Prague Economic Papers, 25(3), 287-303, https://doi.org/10.18267/j.pep. 558

Steurer, R., Konrad, A. (2010). Business-Society Relations in Central-Eastern and Western Europe: How Those Who Lead in Sustainability Reporting Bridge the Gap in Corporate (Social) Responsibility. Scandinavian Journal of Management, 25(1), 23-36, https://doi.org/10.1016/j.scaman.2008.11.001

Strouhal, J., Gurvitš, N., Nikitina-Kalamäe, M., Startseva, E. (2015). Finding the Link between CSR Reporting and Corporate Financial Performance: Evidence on Czech and Estonian Listed Companies. Central European Business Review, 4(3), 48-59, https://doi.org/10.18267/j.cebr.132

Sutantoputra, A. W. (2009). Social Disclosure Rating System for Assessing Firms' CSR Reports. Corporate Communications: An International Journal, 14(1), 34-48, https://doi.org/10.1108/13563280910931063

Wolfe, R., Aupperle, K. (1991). Introduction to Corporate Social Performance: Methods for Evaluating an Elusive Construct, in Post, J. E. ed., Research in Corporate Social Performance and Policy, 12, JAI Press, Greenwich, CT, pp. 265-268. 